\title{
Stock Option Grants And Cost Behavior
}

\author{
Dae-Hyun Kwon, Sookmyung Women's University, Korea
}

\begin{abstract}
This study examines the relation between cost asymmetry and stock option grants. I posit that managers' incentives to decrease the strike price of subsequent option awards may affect manager's resource adjustment decisions. Using U.S. firm data, I find that the degree of $S G \& A$ (selling, general, and administrative) cost asymmetry is positively related to the value of subsequent option grants awarded to the CEOS, suggesting that managers who expect large stock-option grants deliberately delay reduction of committed costs to decrease the share price prior to the option award date. Manipulating the timing of stock option grants do not fully explain the results because the positive relation that this paper documents still holds with only fixed-date option awards sample.
\end{abstract}

Keywords: Stock Option; CEO Compensation; Resource Adjustment; Cost Behavior

\section{INTRODUCTION}

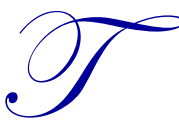

his paper examines whether option grants awarded to the CEOs drive asymmetric behavior of SG\&A cost. Prior studies provide adjustment costs and the manager's expectations for future sales as main drivers of current period resource adjustment decision (Anderson, Banker \& Janakiraman, 2003; Subramaniam \& Weidenmier, 2003; Calleja, Steliaros \& Thomas, 2006; Banker \& Chen, 2006a; Banker, Byzalov, Ciftci \& Mashruwala, 2014). Besides optimal resource planning, managers' incentives to maximize their personal wealth is another primary determinant of asymmetric cost behavior. Recent studies show that self-interested managers give more weights to their personal benefit rather than that of shareholders when they make resource adjustment decision (Chen, Lu \& Sougiannis, 2012; Dierynck, Landsman \& Renders, 2012; Kama \& Weiss, 2013). This study is in line with this research area, focusing on the effect of agency-driven incentives caused by stock option grants on cost asymmetry.

A substantial number of studies document that equity-based compensation tend to motivate managers to act in the interests of shareholders (Jensen \& Meckling, 1976; Gaver \& Gaver, 1993; Hanlon, Rajgopal \& Shevlin, 2003; Efendi, Srivastava \& Swanson, 2007). However, agency theory also indicates that agents will behave opportunistically when their interests differ from that of the principal in the absence of effective monitoring and control mechanisms. Recent studies provide evidence that stock option awards encourage managers to temporarily lower the firm's share price just before stock options are granted. For example, Balsam, Chen, \& Sankaraguruswamy (2003) and Baker, Collins, \& Reitenga (2003) show that managers who anticipate stock option grants manipulate earnings down just prior to the award date to get option grants at low exercise price. However, the research question how the incentives of managers facing subsequent stock option grants influence their cost adjustment decisions has not been investigated.

More sticky cost structure may trigger a larger reduction in earnings for firms than that of less stickiness when sales decrease, because of lower cost savings. A greater decline in current earnings, in turn, may decrease the strike price of subsequent stock option awards by lowering the stock price at the time of the grant. The value of the stock option is based on the difference between the market price of the exercise date and the exercise price of the award date. Naturally, managers who are awarded large amounts of stock option grants have incentive to temporarily lower the share price just before stock options are granted by retaining slack resources when sales drop. Thus, this study hypothesizes that managerial incentives to decrease the stock price at award date affect the degree of asymmetric cost behavior.

Using the U.S. firm observations over the period 1992-2005, this paper finds the positive relationship between the value of subsequent option grants and the degree of asymmetric cost behavior. It is consistent with managers who 
anticipate large subsequent stock option awards intentionally retaining committed resources to lower the strike price of the option awards.

Opportunistic timing of option awards, not delayed reduction of committed resources, may provide alternative explanation for the relation between the degree of cost stickiness and option grants. To mitigate the possibility, this study excludes the firms which are suspected to time or backdate the option awards from the original sample and reestimate the main test model. The positive relation that this paper documents still holds, which indicates that manipulating the timing of stock option grants do not completely explain the results of this study.

This study makes contributions to the literature in the following ways. First, this study integrates two primary research topics of management accounting, CEO compensation and cost behavior by examining whether equity incentives explain asymmetric cost behavior. Second, this study extends contemporaneous accounting research on agency-driven incentives which may diminish or reinforce cost stickiness. While some research document that agency-driven incentives diminish the sticky cost behavior (Dierynck et al., 2012; Kama \& Weiss, 2013), the findings of this paper suggest that managerial incentives may induce cost stickiness, consistent with the findings of Chen et al. (2012). Finally, equity incentives have been viewed as a useful means to align the interests of managers with those of shareholders (Jensen \& Murphy 1990; Gaver \& Gaver 1993; Effend et al., 2007). However, the assumption that the use of equity incentive contributes to better interest alignment has come under scrutiny. Recent studies show that equity incentives motivate managers to act for their own benefit in ways contrary to shareholders' interests. This study adds to the literature by investigating whether self-interested managers subsequent to stock option grants reduce resources beyond optimal level when sales decline, which is contrary to shareholder's interest.

Section 2 next discusses relevant literature and develops the hypothesis. Section 3 presents the sample and the research design. Section 4 elaborates on the empirical results. Section 5 concludes.

\section{HYPOTHESIS DEVELOPMENT}

\section{Option Grants and Cost Stickiness}

Factors affecting managerial decisions to adjust resources when activity level falls are primary interest to the recent accounting literature. Prior studies explain current period resource adjustment decision with adjustment costs and the manager's expectations for future sales (Anderson et al. 2003; Subramaniam \& Weidenmier, 2003; Calleja et al. 2006; Banker \& Chen 2006a; Banker et al. 2014). In addition to traditional explanation for SG\&A cost stickiness phenomenon, recent studies pay considerable attention to managers' incentives to maximize their personal wealth as another determinant of asymmetric cost behavior.

Since managers, who are responsible for cost adjustments, may have their own interests that may not be aligned with those of shareholders, cost behavior is likely to reflect agency consideration, as well as optimal forward looking resource planning based on adjustment cost (Banker, Byzalov \& Dujowich, 2011). Thus, some researchers shed light on the agency-driven cost stickiness. Chen el al. (2012) find that the empire building incentives encourage managers to increase costs quickly in response to demand increase and decrease them slowly when demand decrease. While the empire building incentives reinforce the cost stickiness, manager's incentives to meet or beat earnings targets weakens the asymmetric behavior of costs. Dierynck et al. (2012) provide evidence that when managers tend to meet or beat the zero earnings benchmark, they are likely to increase labor costs below optimal level in response to sales drop and decrease labor costs beyond optimal level in response to sales increase. Kama and Weiss (2013) show that managers who act for their own benefit would expedite reduction of some unused resources when sales decline, in an attempt to meet earnings targets. This paper extends this line of research by investigating whether incentives to lower the exercise price of stock option affect cost asymmetry.

The equity incentive is used to alleviate the conflicting interests resulting from the contracting relationships in the firm which works as a nexus. ${ }^{1}$ The findings of several studies support the efficiency hypothesis_that equity-based compensations reduce agency costs (Murphy, 1985; Smith \& Watts, 1992; Gaver \& Gaver, 1993; Hanlon et al. 2003).

${ }^{1}$ Jensen \& Meckling (1976) articulate the idea that the firm is a nexus consisting of various contracting relationships. 
However, stock options also promote managers' myopic act for their own interest, not for that of shareholders (Cheng \& Lo, 2006; Bergstresser \& Philippon, 2006; Efendi et al. 2007; McAnally, Srivastava \& Weaver, 2008). Recent studies indicate that equity-based compensations motivate managers to temporarily lower the firm's share price just before options are granted, resulting in decreasing the exercise price of the options. Since the value of the stock option is decided based on the difference between the market price of the exercise date and the exercise price of the grant date, decrease in strike price may give much monetary benefit to self-interested managers, even if it decreases firm value. For example, managers opportunistically time bad news to decrease the exercise price of subsequent option awards (Aboody \& Kasznik, 2000; Chauvin \& Shenoy, 2001; Cheng \& Lo, 2006). Moreover, managers who expect large amounts of stock option awards are likely to choose income-decreasing discretionary accruals prior to the grant date (Balsam et al., 2003; Baker, Collins \& Reitenga, 2003). However, the impact of subsequent stock option grants on managers' decision to adjust costs has not been explored ${ }^{2}$.

Facing incentives to decrease the exercise price of upcoming option awards for the purpose of increasing their value, managers who want to maximize their benefit can potentially retain some unused resources when sales drop. Since these delayed resource adjustments lead to a greater reduction in earnings by decreasing cost savings, managers can receive subsequent option grants at low exercise price due to the decline of the stock price at the time of the grant. Therefore, incentives to decrease the stock price at the time of the award reinforce the cost asymmetry. Thus, this paper hypothesizes that resource adjustment decisions made deliberately to lower the exercise price on subsequent option awards increase the degree of asymmetric cost behavior.

H1: The degree of asymmetric cost behavior increases with the magnitude of subsequent stock option grants

\section{RESEARCH SETTING}

\section{Sample}

This study obtains data on CEO compensation variables from ExecuComp database. Since CEOs have ultimate control over resource adjustments, this paper uses compensation data of chief executive officers as a measure of option grants and other incentives (e.g., Yermack, 1997; Burns \& Kedia, 2006; Efendi et al., 2007; Banker, Huang \& Natarajan, 2011). Data on institutional holdings are based on $13 \mathrm{~F}$ filings obtained from CDA Spectrum. Financial data is obtained from the Compustat. Because data on option grants is available until 2005, the sample covers the period from 1992 to 2005.

This paper excludes financial institutions (SIC 6000 - 6099) and drops firm year observations in which sales $t$ salest-1 or $S G \& A_{t} / S G \& A_{t-1}$ are negative, and $S G \& A_{t}$ exceeds salest. Since this study assumes that costs and activity move in the same directions, I drop observations where the direction of changes in SG\&A costs and that of the changes in sales are opposite (Anderson \& Lanen, 2009).

To alleviate the effects of extreme values, this paper excludes all continuous variables which fall at the 1 percent and 99 percent level, and which have studentized residuals greater than 2.5 in absolute values. The final sample contains 7,498 firm year observations.

\section{Variable Measurement}

\section{Compensation Variables}

The variable of interest GRANTED is measured as the fair value of CEO stock option awards in year $\mathrm{t}+1$, calculated using the Black-Scholes option pricing model. (one or two word) Because other CEO pay characteristics affect CEO's cost adjustment decisions, this study employs measures of equity-based and fixed compensation in the research model. Prior research finds that option exercises and option holdings motivate CEOs to manage earnings upward or

\footnotetext{
${ }^{2}$ Banker et al. (2011) argue that new equity-based compensation lead to higher SG\&A expenditure for firms where SG\&A is a strong/substantial source of future firm value. Although their findings are consistent with equity incentives affecting managers' resource adjustment decisions, they do not examine the impact of equity-based compensation on cost asymmetry.
} 
manipulate accounting numbers (Burns \& Kedia, 2006; Bergstresser \& Philippon 2006; Efendi et al., 2007). Thus, managers with large amount of option exercises and holdings are more likely to reduce SG\&A cost when sales decrease. EXERCISES (option exercises) is measured as the intrinsic value of stock options when the CEOs exercises them in the year following the year in which SG\&A cost stickiness is measured (one or two word). Studies by Cheng \& Warfield (2005) and Cohen, Dey \& Thomas (2008) provide evidence that exercisable and unexercisable options have different effects on managers' earnings manipulation behavior. Following their arguments, my empirical model employs measures of unexercisable and exercisable options separately. UN_OPT (EX_OPT) is the intrinsic value of unexercisable (exercisable) options. This paper also includes separate measures of managers' stock ownership: restricted stock holdings (RESTOCK) and stock owned outright (OWN). Since some research show income-increasing earnings management to maximize CEO's bonuses (Healy, 1985; Guidry, Leone \& Rock, 1999; Aboody, Barth \& Kasznik, 2004), large amount of bonus may motivate managers to expedite cuts of committed resources when sales decrease. Thus, this paper also adds CEO's annual bonus (BONUS) in the regression model. This study deflates GRANTED, EXERCISES, UN_OPT, EX_OPT, RESTOCK, OWN by the sum of CEO salary and bonus, and BONUS by salary.

\section{Other Control Variables}

This study includes control variables known as economic conditions which affect the degree of asymmetric cost behavior based on prior literature; asset intensity (ASSETINT), employee intensity (EMPINT) successive sales decrease (DECRE) and GDP growth (GROWTH). Because both asset intensity and employee intensity make it difficult for firms to immediately adjust committed resources when sales drop, those firm characteristics increase cost asymmetry (Anderson et al. 2003; Subramaniam \& Weidenmier, 2003). The asset intensity measure this study constructs is the ratio of total assets to sales, and the employee intensity (EMPINT) is measured as the number of employees divided by sales. On the contrary, when sales drop in both the preceding and the current year, or in periods of macro-economic downturn, cost stickiness is smaller (Anderson et al. 2003; Banker \& Chen, 2006a). DECRE is an indicator variable equal to 1 if sales in year $t-1$ are smaller than those in year $t-2$, and 0 otherwise. GROWTH is the real GDP (domestic national product) growth rate during year $\mathrm{t}$.

In addition to economic determinants of asymmetric behavior of SG\&A cost, this study includes free cash flow (FCF) variable to control for the effect of managers' empire building incentives on the SG\&A cost behavior (Chen et al. 2012). Free cash flow is calculated by subtracting common and preferred dividends from cash flow from operation and dividing the difference by total assets.

\section{TESTS OF HYPOTHESIS}

\section{Descriptive Statistics}

Table 1 presents descriptive statistics for the regression variables. During the sample periods, the mean value of sales and SG\&A cost is $\$ 3,808$ million and $\$ 756$ million, respectively. SG\&A cost is, on average, $24 \%$ of the sales. The number of employees per million dollars in sale is 6.4 and the sample firms utilize 1.07 dollars of assets to produce one dollar of sales on average. The average GDP growth during the sample period is $3.34 \%$. Regarding compensation component, the average fair value of stock option awarded to the CEOs is $\$ 1.7$ million, but the median is only $\$ 630,000$, suggesting diverse stock option activity. Cash compensation is on average $\$ 1.18$ million and the average (median) bonus of sample firms is $\$ 569,000$ ( $\$ 360,000)$. The mean level of option exercises is $\$ 1.4$ million, but the median value is $\$ 0$, suggesting great dispersion of option exercise activity. I define all variables in the Appendix. 
Table 1. Descriptive Statistics

\begin{tabular}{|c|c|c|c|}
\hline & Mean & Median & Std Dev \\
\hline SALE (\$ mil) & 3,808 & 1,060 & 11,200 \\
\hline SG\&A (\$ mil) & 756 & 208 & 2,107 \\
\hline SG\&A to sales ratio & 0.24 & 0.22 & 0.15 \\
\hline DECRE & 0.20 & 0.00 & 0.40 \\
\hline GDP $(\%)$ & 3.34 & 3.50 & 1.11 \\
\hline ASSETINT & 1.07 & 0.92 & 0.64 \\
\hline EMPINT & 6.4 & 5.4 & 4.7 \\
\hline Cash compensation (salary + bonus) $(\$ \mathrm{~K})$ & 1,180 & 920 & 926 \\
\hline Option granted $(\$ \mathrm{~K})$ & 1,679 & 563 & 3,713 \\
\hline GRANTED & 1.33 & 0.63 & 2.19 \\
\hline Option exercises $(\$ \mathrm{~K})$ & 1,445 & 0.00 & 5,875 \\
\hline EXERCISES & 0.94 & 0.00 & 2.40 \\
\hline Unexercisable options $(\$ \mathrm{~K})$ & 2,444 & 384 & 6,847 \\
\hline UN_OPT & 1.84 & 0.41 & 3.71 \\
\hline Exercisable options (\$ K) & 5,900 & 1,133 & 15,500 \\
\hline EX_OPT & 4.34 & 1.26 & 8.46 \\
\hline Bonus (\$ K) & 569 & 360 & 712 \\
\hline BONUS & 0.84 & 0.71 & 0.79 \\
\hline Restricted stock holdings (\$ K) & 845 & 0.00 & 2,895 \\
\hline RESTOCK & 0.51 & 0.00 & 1.27 \\
\hline Stock owned outright (\$ K) & 48,900 & 5,901 & 229,000 \\
\hline OWN & 55.16 & 5.42 & 189.83 \\
\hline FCF & 0.10 & 0.09 & 0.07 \\
\hline
\end{tabular}

1. See Appendix for variable definitions.

Table 2 reports the Pearson correlation matrix of the variables in my study. The correlations between pairs of control variables are generally small, suggesting that multicollinearity is not a problem. 
Table 2. Pearson Correlation among Regression Variables

\begin{tabular}{|c|c|c|c|c|c|c|c|c|c|}
\hline & $\Delta \operatorname{lnSALE}$ & DECRE & GDP & \multicolumn{2}{|c|}{ ASSETINT } & \multicolumn{2}{|c|}{ EMPINT } & GRANTED & \multirow[t]{2}{*}{ EXERCISES } \\
\hline$\Delta \ln \mathrm{SALE}$ & 1.000 & & & & & & & & \\
\hline DECRE & $-0.2095^{* * *}$ & 1.000 & & & & & & & \\
\hline GDP (\%) & $0.1568^{* * *}$ & $-0.0890^{* * *}$ & 1.000 & & & & & & \\
\hline ASSETINT & $0.0440^{* * *}$ & $0.0811^{* * *}$ & $-0.0601^{* * *}$ & \multicolumn{2}{|c|}{1.000} & & & & \\
\hline EMPINT & $-0.0206^{* * *}$ & $-0.0506^{* * *}$ & $0.0406^{* * *}$ & \multicolumn{2}{|c|}{$-0.1200^{* * *}$} & \multicolumn{2}{|c|}{1.000} & & \\
\hline GRANTED & $0.1291^{* * *}$ & $-0.0614^{* * *}$ & $0.0351^{* * *}$ & \multicolumn{2}{|c|}{$0.1383^{* * *}$} & \multicolumn{2}{|c|}{$-0.058^{* * *} 9$} & 1.000 & \\
\hline EXERCISES & $0.1407^{* * *}$ & $-0.0769^{* * *}$ & -0.0130 & \multicolumn{2}{|c|}{$0.0860^{* * *}$} & \multicolumn{2}{|c|}{-0.018} & $0.1926^{* * *}$ & 1.000 \\
\hline UN_OPT & $0.1965^{* * *}$ & $-0.0735^{* * *}$ & $0.0357^{* * *}$ & \multicolumn{2}{|c|}{$0.0859^{* * *}$} & \multicolumn{2}{|c|}{$-0.0244^{* *}$} & $0.3078^{* * *}$ & $0.3165^{* * *}$ \\
\hline EX_OPT & $0.1699^{* * *}$ & $-0.1027^{* * *}$ & 0.0020 & \multicolumn{2}{|c|}{$0.1186^{* * *}$} & \multicolumn{2}{|c|}{$-0.0393^{* * *}$} & $0.2820^{* * *}$ & $0.3004^{* * *}$ \\
\hline RESTTOCK & $-0.0665^{* * *}$ & $0.0257^{* *}$ & $-0.0313^{* * *}$ & \multicolumn{2}{|c|}{0.0050} & \multicolumn{2}{|c|}{$-0.0563^{* * *}$} & -0.0110 & -0.0050 \\
\hline OWN & $0.0855^{* * *}$ & $-0.0614^{* * *}$ & $0.0307^{* * *}$ & \multicolumn{2}{|c|}{-0.0110} & \multicolumn{2}{|c|}{$0.0531^{* * *}$} & 0.0050 & -0.0010 \\
\hline BONUS & $0.1707^{* * *}$ & $-0.0436^{* * *}$ & $0.0248^{* *}$ & \multicolumn{2}{|c|}{0.0040} & \multicolumn{2}{|c|}{$-0.1614^{* * *}$} & $0.0559^{* * *}$ & $0.0569^{* * *}$ \\
\hline FCF & $0.0759^{* * *}$ & $-0.1146^{* * *}$ & $-0.0329^{* * *}$ & \multicolumn{2}{|c|}{$-0.0737^{* * *}$} & \multicolumn{2}{|c|}{$0.0498^{* * *}$} & $0.084^{* * *} 0$ & $0.1334^{* * *}$ \\
\hline & UN_OPT & EX_OPT & \multicolumn{2}{|c|}{ RESTOCK } & \multicolumn{2}{|c|}{ OWN } & & BONUS & FCF \\
\hline UN_OPT & 1.000 & & & & & & & & \\
\hline EX_OPT & $0.4594^{* * *}$ & 1.000 & & & & & & & \\
\hline 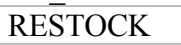 & 0.0120 & 0.0120 & \multicolumn{2}{|c|}{1.000} & & & & & \\
\hline OWN & $0.0222^{*}$ & \multirow{2}{*}{0.0080} & \multicolumn{2}{|c|}{$-0.0636^{* * *}$} & \multicolumn{2}{|c|}{1.000} & & & \\
\hline BONUS & $0.1155^{* * *}$ & & 0.0 & $48^{* * *}$ & & $042^{* * *}$ & & 1.000 & \\
\hline FCF & $0.1891^{* * *}$ & 0.1635 & -0.0 & & & $822^{* * *}$ & & $0.1562^{* * *}$ & 1.000 \\
\hline
\end{tabular}

1. See Appendix for variable definitions.

2. *,***** indicate statistical significance at the $10 \%, 5 \%$, and $1 \%$ respectively (two-tailed test)

\section{Empirical Models and Results}

\section{Cost Stickiness and Option Grants}

In testing $\mathrm{H}_{1}$, this paper performs a regression analysis using the following model:

$$
\begin{aligned}
& \Delta \operatorname{lnSG\& Ai_{i,t}}=\beta_{0}+\beta_{1} \Delta \operatorname{lnSALE}_{i, t}+\beta_{2} \Delta \operatorname{lnSALE}_{i, t} * \operatorname{Nega}_{i, t}+\beta_{3} \Delta \operatorname{lnSALE}{ }_{i, t} * \operatorname{Nega}_{i, t} \\
& * \operatorname{GRANTED}_{i, t+1}+\beta \Delta \operatorname{lnSALE}_{i, t} * \mathrm{Nega}_{i, t} * \mathrm{FCF}_{i, t}+\sum \beta \cdot \mathrm{CEO}_{\text {Incentives }} * \Delta \operatorname{lnSALE}_{i, t} \\
& * \text { Nega }_{i, t}+\sum \beta \cdot \text { Econ_Controls } * \Delta \operatorname{lnSALE}_{i, t} * \text { Nega }_{i, t}+\beta \text { GRANTED }_{i, t+1}+\beta \text { FCF }_{i, t}+\sum \beta \text {. } \\
& \text { CEO_Incentives }_{i, t}+\sum \beta \cdot \text { Econ_Controls }_{i, t}+\sum \beta \text { Year Fixed effects }_{-}+\varepsilon_{\mathrm{i}, \mathrm{j}, \mathrm{t}}
\end{aligned}
$$

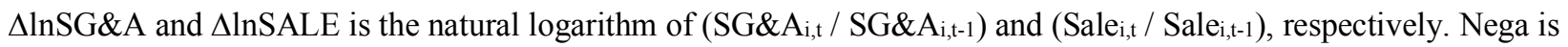
an indicator variable set to 1 if sales in year $t$ are smaller than those in year $t-1,0$ otherwise. Econ_Controls consists of previously defined economic determinants which influence the asymmetric behavior of SG\&A cost: asset intensity, employee intensity, successive sales decrease and macro-economic growth.

Hypothesis 1 predicts a negative coefficient on $\beta_{3}, \Delta \operatorname{lnSALE}{ }_{\mathrm{i}, \mathrm{t}} * \mathrm{Nega}_{\mathrm{i}, \mathrm{t}} *$ GRANTED interaction. Equation (1) allows me to control for conflicting CEO incentives that may affect the asymmetric cost behavior, together with economic conditions. CEO_incentives include EXERCISES (option exercise), UN_OPT (unexercisable options held), EX_OPT (exercisable options held), RESTOCK (CEO's restricted stock holdings), OWN (CEO's stock owned outright) and BONUS (annual cash bonus).

The coefficient estimates of equation (1) reported in Table 3 provide the tests of $\mathrm{H} 1$. This study uses clustered standard errors to control for heteroskedasticity and serial correlation (Petersen 2009). The coefficient on the interaction term which includes GRANTED ( $\triangle \operatorname{lnSALE} *$ Nega*GRANTED) is significantly negative (coefficient $=-0.0086, \mathrm{t}=1.96$ ), consistent with Hypothesis 1. It suggests that asymmetric cost behavior becomes more severe when the value of subsequent option grants awarded to the CEOs increases. The positive association this study documents could result from managers who expect large amounts of stock option awards intentionally delaying reduction in committed 
resources to lower the exercise price of option grants. Turning to the control variables, the estimated coefficient on bonus $(\triangle \operatorname{lnSALE} *$ Nega*BONUS) and restricted stock holdings ( $\triangle \operatorname{lnSALE} *$ Nega*RESTOCK) are positive and significant, indicating that managers opportunistically reduce costs beyond optimal level to increase their annual cash bonus and maximize their restricted stock. These conflicting results are consistent with those of McAnally et al. (2008), arguing the existence of the trade-off among incentives. The signs of the coefficients on unexercisable/exercisable options and restricted stock holdings/stock owned outright are opposite, but those of managers' stock ownership alone are significant. This paper finds insignificant effects of option exercises ( $\triangle \operatorname{lnSALE}$ *Nega*EXERCISES) and free cash flow ( $\triangle$ InSALE *Nega*FCF) on SG\&A cost asymmetry.

Table 3. Results of Regressing SG\&A Cost Changes on Stock Option Grants

\begin{tabular}{|c|c|c|c|}
\hline Variables & Predicted Sign & Coefficient & t-statistics \\
\hline Constant & & $0.0307^{* * *}$ & $(5.77)$ \\
\hline$\Delta \operatorname{lnSALE}$ & + & $0.7777^{* * *}$ & $(75.17)$ \\
\hline$\Delta \operatorname{lnSALE} *$ Nega & - & $-0.1181^{* *}$ & $(-1.78)$ \\
\hline$\Delta \operatorname{lnSALE} *$ Nega*GRANTED & - & $-0.0108^{* *}$ & $(-1.80)$ \\
\hline$\triangle \operatorname{lnSALE} *$ Nega*EXERCISES & & -0.0116 & $(-1.16)$ \\
\hline$\Delta \operatorname{lnSALE} *$ Nega*UN_OPT & & 0.0054 & $(0.85)$ \\
\hline$\Delta \operatorname{lnSALE} *$ Nega*EX_OPT & & -0.0052 & $(-1.63)$ \\
\hline$\triangle \operatorname{lnSALE} *$ Nega*RESTOCK & & $0.0307^{* *}$ & $(2.55)$ \\
\hline$\Delta \operatorname{lnSALE} *$ Nega $*$ OWN & & $-0.0002^{* * *}$ & $(-3.35)$ \\
\hline$\Delta \operatorname{lnSALE} *$ Nega*BONUS & & $0.0934^{* * *}$ & $(3.39)$ \\
\hline$\Delta \operatorname{lnSALE} *$ Nega*FCF & & 0.1338 & $(0.50)$ \\
\hline$\triangle \operatorname{lnSALE} * \mathrm{Nega} *$ DECRE & & $0.1064^{* * *}$ & $(2.93)$ \\
\hline$\Delta \operatorname{lnSALE} *$ Nega $*$ GROWTH & & 0.0148 & $(1.09)$ \\
\hline$\Delta \operatorname{lnSALE} *$ Nega $*$ ASSETINT & & $-0.0852^{* * *}$ & $(-3.81)$ \\
\hline$\Delta \operatorname{lnSALE} *$ Nega $*$ EMPINT & & $0.1276^{* * *}$ & $(2.63)$ \\
\hline GRANTED & & $-0.0014^{* * *}$ & $(-2.88)$ \\
\hline EXERCISES & & -0.0000 & $(-0.06)$ \\
\hline UN_OPT & & -0.0000 & $(-0.07)$ \\
\hline EX_OPT & & $0.0002^{*}$ & $(1.87)$ \\
\hline RESTTOCK & & -0.0003 & $(-0.50)$ \\
\hline OWN & & $0.0001^{* * *}$ & $(3.23)$ \\
\hline BONUS & & -0.0007 & $(-0.59)$ \\
\hline FCF & & $-0.0538^{* * *}$ & $(-3.30)$ \\
\hline DECRE & & $-0.0240^{* * *}$ & $(-9.93)$ \\
\hline GROWTH & & 0.0007 & $(0.56)$ \\
\hline ASSETINT & & -0.0010 & $(-0.54)$ \\
\hline EMPINT & & $0.0097^{* * *}$ & $(4.72)$ \\
\hline Year Dummies & & \multicolumn{2}{|c|}{ Included } \\
\hline Observations & & \multicolumn{2}{|c|}{7,498} \\
\hline Adjusted R-squared & & \multicolumn{2}{|c|}{0.775} \\
\hline
\end{tabular}

1. See Appendix for variable definitions.

2. This study uses standard errors clustered by firms (Petersen 2009).

3. Influential observations with Studentized residuals greater than 2.5 are excluded.

4. $*, *, * * *$ indicate statistical significance at the $10 \%, 5 \%$, and $1 \%$ respectively (one-tailed for predicted signs, two-tailed otherwise).

\section{Additional Tests}

This paper believes that the positive relation between stock option awards and the degree of asymmetric behavior of SG\&A costs comes from manager's intentional retention of slack resources to maximize option award value. However, several recent studies show that managers tend to backdate their stock option grants (Heron \& Lie, 2007). Thus, opportunistic timing of option awards, not delaying cuts of committed resources, may explain the relation between the degree of cost stickiness and option awards. To mitigate the possibility, this study retains the fixed-date option awards sample and re-estimate the main test model. 
Following the prior literature, this study infers the option award date from the expiration date of the option, based on the assumption that the option maturities are expressed in whole years. It identifies an award as a fixed date option award if the award date is within 2 weeks of the option award date in either of the previous two fiscal years, i.e., if more than one grant occurs within a 2 week-period over three years.

Table 4. Tests of the Impact of Option Grants on SG\&A Cost Asymmetry: Fixed-date Option Awards Sample

\begin{tabular}{|c|c|c|c|}
\hline Variables & Predicted Sign & Coefficient & t-statistics \\
\hline Constant & & $0.0181^{*}$ & $(1.90)$ \\
\hline$\Delta \operatorname{lnSALE}$ & + & $0.7560^{* * *}$ & $(37.45)$ \\
\hline$\Delta \operatorname{lnSALE} *$ Nega & - & -0.1171 & $(-0.90)$ \\
\hline$\Delta \operatorname{lnSALE} *$ Nega*GRANTED & - & $-0.0255^{* *}$ & $(-2.14)$ \\
\hline$\Delta \operatorname{lnSALE} *$ Nega $*$ EXERCISES & & $0.0312^{*}$ & $(1.79)$ \\
\hline$\Delta \operatorname{lnSALE} *$ Nega $*$ OPT & & $-0.0313^{* * *}$ & $(-4.54)$ \\
\hline$\Delta \operatorname{lnSALE} *$ Nega $*$ OWN & & $-0.0003^{* *}$ & $(-2.25)$ \\
\hline$\Delta \operatorname{lnSALE} *$ Nega $*$ BONUS & & 0.0879 & $(1.07)$ \\
\hline$\Delta \operatorname{lnSALE} *$ Nega $*$ FCF & & $1.1990^{*}$ & $(1.90)$ \\
\hline Controls & & \multicolumn{2}{|c|}{ Included } \\
\hline Year Dummies & & \multicolumn{2}{|c|}{ Included } \\
\hline Observations & & \multicolumn{2}{|c|}{1,737} \\
\hline Adjusted R-squared & & \multicolumn{2}{|c|}{0.777} \\
\hline
\end{tabular}

1. See Appendix for variable definitions.

2. This study uses standard errors clustered by firms (Petersen 2009).

3. Influential observations with Studentized residuals greater than 2.5 are excluded.

4. *,**,** indicate statistical significance at the $10 \%, 5 \%$, and $1 \%$ respectively (one-tailed for predicted signs, two-tailed otherwise).

The test results are presented in Table 4 . This study continues to find the statistically significantly negative coefficient on the interaction term of GRANTED $\left(\beta_{3}=-0.025, \mathrm{t}=-2.14\right)$, which indicates that the opportunistic timing of option grants do not fully explain the main results. ${ }^{3}$

As an additional test, following Li, Wasley \& Zimmerman (2011), this paper excludes the firms which are listed in The Wall Street Journal's "Options Scorecard" on September 4, 2007 for allegedly engaging in stock option backdating and re-estimate equation (1). Untabulated result shows a negative and significant coefficient on $\triangle \operatorname{lnSALE}$ $\mathrm{i}, \mathrm{t} * \mathrm{Nega} \mathrm{i},{ }^{*}$ GRANTED interaction $\left(\beta_{3}=-0.025, \mathrm{t}=-2.14\right)$, consistent with the hypothesis.

\section{CONCLUSION}

This study examines whether managers who anticipate large subsequent option awards intentionally delay the reduction of slack in SG\&A costs to lower the exercise price of stock-option awards. Consistent with the prediction, this study finds that the higher the subsequent option grants, the higher the observed cost stickiness, suggesting that incentives to receive subsequent option grants at low exercise price on the option award date can affect managers' resource adjustments decision. Since the positive relation that this paper documents still holds using the sample firms which grant on approximately the same calendar date each year, manipulating the timing of stock option grants do not fully explain the results.

This study integrates two primary research topics of management accounting, CEO compensation and cost behavior by showing that equity incentives influence managers' decisions to adjust costs. In addition, this study may develop our understanding of the impact of agency-driven incentive on cost behavior. Although this study shed light on the CEO compensations that may affect cost behavior, future research could investigate the impact of other CEO characteristics on resource adjustment decisions.

\footnotetext{
${ }^{3}$ Since the sample size is relatively small compared with the number of current control variables in this test, this study reduces the number of control variables by uniting two variables into one: exercisable (EX_OPT) and unexercisable (UN_OPT) options into options (OPT), and restricted stock holdings (RESTOCK) and stock owned outright (OWN) into CEO ownership (OWN).

${ }^{4} \mathrm{http} / / /$ online.wsj.com/public/resources/documents/info-optionsscore06-full.html
} 


\section{AUTHOR BIOGRAPHY}

Dae-Hyun Kwon is an associate professor in Department of Business Administration at Sookmyung Women's University. Research interests are compensation, cost behaviour, corporate governance, and employee characteristics.

\section{REFERENCES}

Aboody, D., \& Kasznik, R. (2000). CEO stock option awards and the timing of corporate voluntary disclosures. Journal of Accounting and Economics, 29(1), 73-100.

Aboody, D., Barth, M. E., \& Kasznik, R. (2004). Firms' voluntary recognition of stock-based compensation expense. Journal of Accounting Research, 42(2), 123-150.

Anderson, M. C., Banker, R. D. \& Janakiraman, S. N. (2003). Are selling, general, and administrative costs 'sticky'? Journal of Accounting Research, 41(1), 47-63.

Anderson, S., \& W. Lanen. (2009). Understanding cost management: What can we learn from the evidence on 'sticky costs? Working paper, Rice University.

Baker, T., Collins, D., \& Reitenga, A. (2003). Stock-option compensation and earnings management incentives. Journal of Accounting, Auditing and Finance, 18(4), 557-582.

Balsam, S., Chen, H., \& Sankaraguruswamy, S. (2003). Earnings management prior to stock-option grants. Working paper, Temple University.

Banker, R. D., \& Chen, L. (2006a). Labor market characteristics and cross-country differences in cost stickiness. Working paper.

Banker, R., Byzalov, D., \& Dujowich, J. M. (2011). Sticky cost behavior: theory and evidence. Working paper, Temple University.

Banker, R. D., Byzalov, D., Ciftci, M., \& Mashruwala, R. (2014). The moderating effect of prior sales changes on asymmetric cost behavior. Journal of Management Accounting Research, 26(2), 221-242.

Banker, R. D., Huang, R., \& Natarajan, R. (2011). Equity incentives and long-term value created by SG\&A expenditure. Contemporary Accounting Research, 28(3), 794-830.

Bergstresser, D., \& Philippon, T. (2006). CEO incentives and earnings management. Journal of financial economics, 80(3), 511529.

Burns, N., and Kedia, S. (2006). The impact of performance-based compensation on misreporting. Journal of Financial Economics, 79(1), 35-67.

Calleja, K., Steliaros, M., \& Thomas, D. C. (2006). A note on cost stickiness: Some international comparisons. Management Accounting Research, 17(2), 127-40.

Chauvin, K. W., \& Shenoy, C. (2001). Stock price decreases prior to executive stock-option grants. Journal of Corporate Finance, 7(1), 53-76.

Chen, C. X., Lu, H., \& Sougiannis, T. (2012). The agency problem, corporate governance, and the asymmetrical behavior of selling, general, and administrative costs. Contemporary Accounting Research, 29(1), 252-282.

Cheng, Q., \& Lo, K. (2006). Insider trading and voluntary disclosures. Journal of Accounting Research, 44(4), $815-848$.

Cheng, Q., \& Warfield, T. D. (2005). Equity incentives and earnings management. The Accounting Review, 80(2), 441-476.

Cohen, D. A., Dey, A., \& Thomas, T. Z. (2008). Real and accrual-based earnings management in the pre- and post-SarbanesOxley periods. The Accounting Review, 83(3), 757-787.

Dierynck, B., Landsman, W. R., \& Renders, A. (2012). Do managerial incentives drive cost behavior? Evidence about the role of the zero earnings benchmark for labor cost behavior in private Belgian firms. The Accounting Review, 87(4), $1219-1246$.

Efendi, J., Srivastava, A., \& Swanson, E. (2007). Why do corporate managers misstate financial statements? The role of in-themoney options and other incentives. Journal of Financial Economics, 85(3), 667-708.

Gaver, J. J., \& Gaver, K. M. (1993). Additional evidence on the association between the investment opportunity set and corporate financing, dividend and compensation policies. Journal of Accounting and Economics, 16(1-3), 125-160.

Guidry, F., Leone, A. J., \& Rock, S. (1999). Earnings-based bonus plans and earnings management by business-unit managers. Journal of Accounting and Economics, 26(1), 113-142.

Hanlon, M., Rajgopal, S., \& Shevlin. T. (2003). Are executive stock options associated with future earnings? Journal of Accounting and Economics, 36(1-3), 3-43.

Healy, P. (1985). The effect of bonus schemes on accounting decisions. Journal of Accounting and Economics, 7(1-3), 85-107.

Heron, R., \& Lie, E. (2007). Does backdating explain the stock price pattern around executive stock option grants? Journal of Financial Economics, 83(2), 271-295.

Jensen, M. C., \& Murphy, K. J. (1990). Performance pay and top-management incentives. Journal of Political Economy, 98(2), 225-64.

Jensen, M. C., \& Meckling, W. H. (1976). Theory of the firm: managerial behavior, agency costs and ownership structure. Journal of Financial Economics, 3(4), 305-360.

Kama, I., \& Weiss, D. (2013). Do earnings targets and managerial incentives affect sticky costs? Journal of Accounting Research, 51(1), 201-224. 
Li, E., Wasley, C., \& Zimmerman, J. (2011). A Unified framework of management earnings forecasts: voluntary, disclose or abstain, and opportunistic incentives. Working paper, University of Rochester.

McAnally, L. M., Srivastava, A., and Weaver, C. D. (2008). Executive stock options, missed earnings targets, and earnings management. The Accounting Review, 83(1), 185-216.

Murphy, K. (1985). Corporate performance and managerial remuneration: An empirical analysis. Journal of Accounting and Economics, 7(1-3), 11-42.

Petersen, M. A. (2009). Estimating standard errors in finance panel data sets: Comparing approaches, Review of Financial Studies, 22(1), 435-80.

Smith, C. W., \& Watts, R. L. (1992). The investment opportunity set and corporate financing, dividend, and compensation policies. Journal of Financial Economics, 32(3), 263-292.

Subramaniam, C., \& Weidenmier, M. L. (2003). Additional evidence on the sticky behavior of costs. Working paper, Texas Christian University and University of Texas at Arlington.

Yermack, D. (1997). Good timing: CEO stock option awards and company news announcements. Journal of Finance, 52(2), 449-476. 


\section{APPENDIX}

\begin{tabular}{|c|c|}
\hline \multicolumn{2}{|r|}{ Variable Definitions } \\
\hline Dependent Variables & \\
\hline$\Delta \mathrm{SG} \& \mathrm{~A}$ & $=\log \left(S G \& A \operatorname{cost}_{i, t} / S G \& A \operatorname{cost}_{i, t-1}\right)$ \\
\hline \multicolumn{2}{|l|}{ Independent Variables } \\
\hline$\triangle$ SALE & $=\log \left(\right.$ sales $_{i, t} /$ sales $\left._{i, t-1}\right)$ \\
\hline Nega & $=$ indicator variable which takes the value of 1 if sales are negative, zero otherwise \\
\hline GRANTED & $\begin{array}{l}=\text { The CEO's estimated fair value of options awards using the Black-Scholes model, scaled by the } \\
\text { sum of salary and bonus }\end{array}$ \\
\hline EXERCISES & $\begin{array}{l}=\text { The intrinsic value of stock options when the CEO exercises them, scaled by the sum of salary } \\
\text { and bonus }\end{array}$ \\
\hline UN_OPT & $=$ The intrinsic value of the CEO's unexercisable options, scaled by the sum of salary and bonus \\
\hline EX_OPT & $=$ The intrinsic value of the CEO's exercisable options, scaled by the sum of salary and bonus \\
\hline BONUS & $=$ The CEO's annaul cash bonus, scaled by salary \\
\hline RESTOCK & $=$ The CEO's restricted stock holdings, scaled by the sum of salary and bonus \\
\hline OWN & $=$ The CEO's stock owned outright, scaled by the sum of salary and bonus \\
\hline FCF (Free Cash Flow) & $=$ cash flow from operation minus common and preferred dividends, scaled by total assets \\
\hline DECRE & $=$ indicator variable set to 1 if sales of $\mathrm{t}-1$ year is smaller than sales of $\mathrm{t}-2$ year, zero otherwise \\
\hline GROWTH & $=$ the percentage growth in real GDP during year $\mathrm{t}$ \\
\hline ASSETINT & $=$ total asset scaled by sales \\
\hline EMPINT & $=$ the number of employees, scaled by sales \\
\hline
\end{tabular}


NOTES 